\title{
Economic study of the treatment of surface water by small ultrafiltration units
}

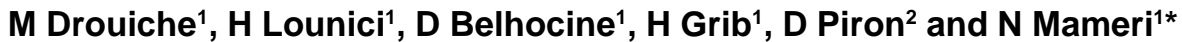 \\ 1 Ecole Nationale Polytechnique d'Alger, 10 Avenue Pasteur, 16200, El-Harrach, Alger, Algeria \\ ${ }^{2}$ Ecole Polytechnique de Montréal, B.P.6079. Station Centre-ville, Montréal, Qc, Canada H3C 3A7
}

\begin{abstract}
The purpose of this work is to evaluate the possibility of utilising an ultrafiltration process for the treatment of water from the dam in the Kabylia region of Algeria and, in particular, for the provision of drinking water to people living in dispersed small villages. The water quality was determined by measuring turbidity, and natural organic matter concentration. The results obtained with an ultrafiltration process indicate that this technique can considerably reduce suspended and organic matter. It also improves the bacteriological quality of the treated water. An economic evaluation for ultrafiltration of surface water is presented. The economic study was performed for a drinking water unit of $20 \mathrm{~m}^{3} / \mathrm{h}$. It was found that the cost per $\mathrm{m}^{3}$ of treated water $\left(\$ 0.235 / \mathrm{m}^{3}\right)$ obtained would not be excessively high for the states of the North African region.
\end{abstract}

\section{Notation}

$\mathrm{J}_{\mathrm{v}} \quad$ Permeate flux $\left(\ell / \mathrm{h} \cdot \mathrm{m}^{2}\right)$

OD $\quad$ Optic density of the concentrate solution

$\mathrm{OD}_{\mathrm{p}}$ Optic density of the permeate solution

$\mathrm{P}_{\mathrm{o}} \quad$ Oulet membrane pressure $(\mathrm{Pa})$

$\mathrm{P}_{1} \quad$ Inlet membrane pressure $(\mathrm{Pa})$

$\mathrm{R}_{\mathrm{OD}} \quad$ Experimental apparent rejection coefficient based on optic density $(\%)$

$\mathrm{R}_{\mathrm{Tur}} \quad$ Experimental apparent rejection coefficient based on turbidity $(\%)$

$\mathrm{T} \quad$ Temperature $\left({ }^{\circ} \mathrm{C}\right)$

Tur $_{c} \quad$ Turbidity of the concentrate solution (NTU)

Tur $_{\mathrm{p}} \quad$ Turbidity of the permeate solution (NTU)

U Tangential velocity $(\mathrm{m} / \mathrm{s})$

UF Ultrafiltration process

DP Average transmembrane pressure $(\mathrm{Pa})$

\section{Introduction}

Access to water as a natural resource is a serious problem in the North African region. The treatment of water before distribution to people is essential in order to maintain quality of life. The North African population is increasing and the greatest rate of future growth will be in cities. Governments in this region use the full extent of economic capacity and current knowledge to develop acceptable urban environments and an efficient water supply. Lower priority is given to supplying water to small villages dispersed in the North African region. The long distances between the water reservoirs and these villages, as well as the tropical temperature of this region, necessitate a chlorine disinfection process which, as result of the presence of natural organic matter (NOM) in the raw water, may lead to the formation of carcinogenic by-products. Furthermore, the digestible organic carbon present in NOM leads to a potential for bacterial regrowth in distribution

\footnotetext{
* To whom all correspondence should be addressed.

勈(514) 3404710 x 4763; fax (514) 3404167 ;

e-mail: nabil.mameri@courriel.polymtl.ca

Received 8 May 2000; accepted in revised form 25 January 2001.
}

systems (Lin et al., 2000).

The required conformity to microbiological standards for drinking water cannot be guaranteed cost-effectively by conventional technologies (Brugger, 2000). Membrane technology has been utilised to solve this problem, and the efficiency of this process has made it possible to increase the quantity and the quality of drinking water distributed to the rural population (Lin et al., 2000; Jolis et al., 1999 and Yuasa, 1998, Magara et al., 1998; Brahiti et al., 1994, Anselme et al., 1992, Tazi-Pain et al., 1992; Bersillon et al., 1989).

The main purpose of this work was to investigate the operation and efficiency of ultrafiltration in the treatment of surface water to drinking water standards for supply to small villages of the Kabylia region, with populations not exceeding 3000 . In the present study, an organic ultrafiltration membrane was used to treat surface water collected from the Keddara Dam under various experimental conditions. The effect of average transmembrane pressure $(P)$ and tangential flow rate $(U)$ on the performance of ultrafiltration membranes was measured. Raw water was treated by ultrafiltration under optimal conditions (tangential velocity and average transmembrane pressure), and an economic study of the membrane process was conducted.

\section{Materials and methods}

The main physico-chemical characteristics of Keddara Dam water are presented in Table 1 . The water quality was determined by measuring the following parameters (Lefebvre, 1995): $\mathrm{pH}$ (WTW, model 1223), conductivity (TOA model CM-8ET), turbidity (HACH, model 2100A) and optic density at $254 \mathrm{~nm}$ and $270 \mathrm{~nm}$ (MILTON ROY UV/Vis spectrophotometer, model Spectronic 1201). The latter two determinants express values for suspended matter and dissolved organic matter in the raw water. The bacteriological quality of the water is evaluated by determining biological cell counts by the spread-plate method (ASM, 1987).

Ultrafiltration experiments were performed using the Microlab $130 \mathrm{~S}$ pilot unit made by Gamma Filtration, France. It was equipped with an organic Patterson Candy International (PCI-BX6) membrane with a molecular mass cut-off of $20 \mathrm{kDa}$. The PCI module was composed of 18 tubular polysulfone membranes with a length of 


\begin{tabular}{|l|c|}
\hline \multicolumn{2}{|c|}{ TABLE 1 } \\
Typical range of raw water quality parameters from \\
Keddara Dam \\
\hline Determinant & Monthly average range \\
\hline $\mathrm{pH}$ & $7.8-8.1$ \\
Conductivity $(\mathrm{mS} / \mathrm{cm})$ & $1.03-1.20$ \\
Turbidity $(\mathrm{NTU})$ & $1.2-1.6$ \\
Optic density $254 \mathrm{~nm}$ & $0.051-0.068$ \\
Optic density $270 \mathrm{~nm}$ & $0.047-0.063$ \\
Oxidation $\mathrm{KMnO}_{4}(\mathrm{mg} / \ell)$ & $3.4-4.2$ \\
Total coliform $\left(10^{6} \mathrm{cfu} / 100 \mathrm{~m} \ell\right)$ & $0.35-0.77$ \\
\hline
\end{tabular}

a

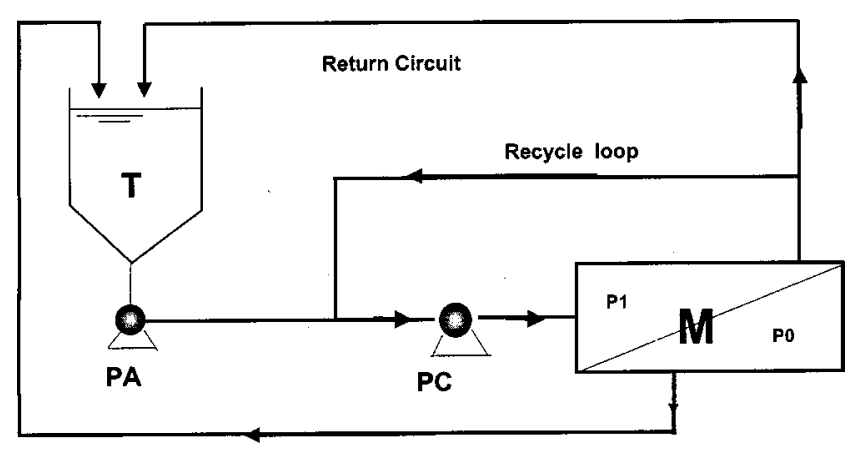

b

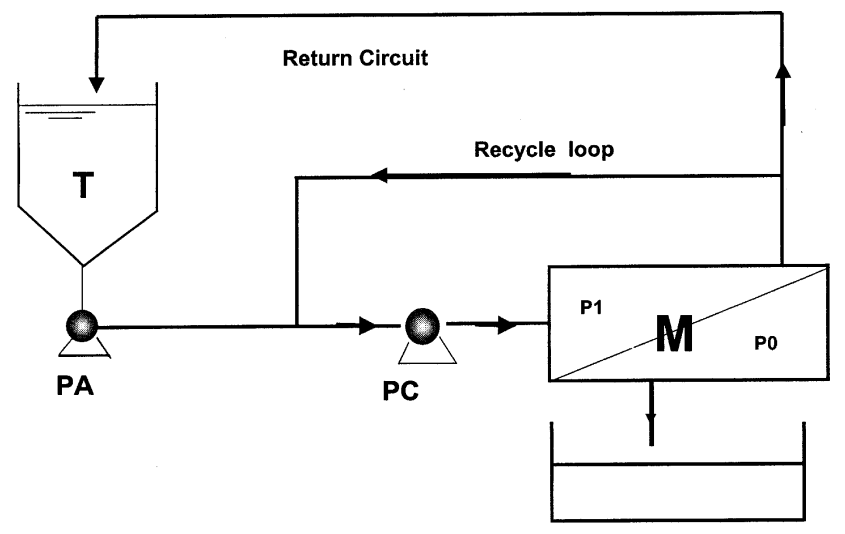

Figure 1

Schematic representation of the ultrafiltration process. Ultrafiltration with (a) and without recycling permeate (b).

T: Feed tank; PC: Recycling pump; PA: Feed pump;

$M$ : ultrafiltration module. $P_{o}:$ Outlet membrane pressure ; $P_{1}:$ Inlet membrane pressure .

$1.2 \mathrm{~m}$ and an internal diameter of $12.5 \mathrm{~mm}$, yielding a total filtration area of $0.86 \mathrm{~m}^{2}$.

Two operating modes were used (Fig. 1). The first mode consisted of ultrafiltration with permeate recycling. It allowed the study of the influence of the hydrodynamic parameters on the performance of the ultrafiltration process for an initial raw water concentration. The second operating mode was used to study raw water treatment by ultrafiltration. In this mode, no permeate recirculation to the feed tank of $25 \ell$ capacity was used. The ultrafiltration experiments were conducted at $20^{\circ} \mathrm{C}$ under an average

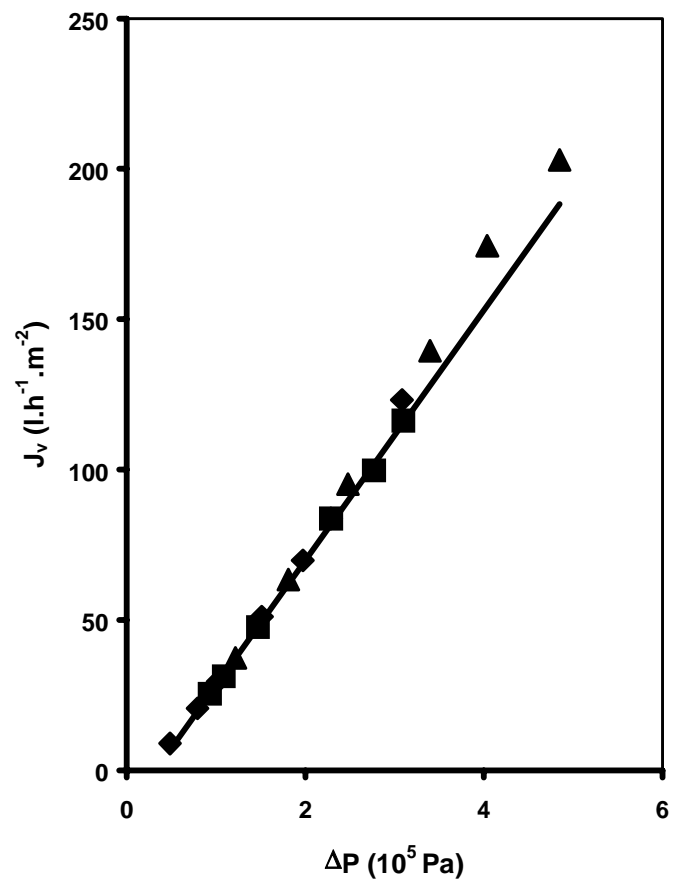

Figure 2

Influence of tangential flow rate and average transmembrane pressure on permeate flux $\left(J_{v}\right)$. (*) $U=0.3 \mathrm{~m} / \mathrm{s},(-) U=0.6 \mathrm{~m} / \mathrm{s}$ and (४) $U=0.7 \mathrm{~m} / \mathrm{s}$

transmembrane pressure $\left(P_{0}+P_{1}\right) / 2$ of between 50 and $350 \mathrm{kPa}$. All experiments were duplicated, and the experimental error did not exceed $8 \%$.

\section{Results and discussion}

\section{Influence of hydrodynamic parameters on permeate flux}

The influence of the average transmembrane pressure (DP) and the tangential flow rates $(U)$ on the permeate flux $J_{v}$ was studied with permeate recycling. From the results shown in Fig. 2, it can be deduced that the variation of the permeate flux was practically independent of $U$ in the range tested. The results also show that a linear relationship exists between $\mathrm{J}_{v}$ and $\mathrm{D} P$, which indicates that polarisation and fouling phenomena were not predominant under the prevailing operating conditions, since at higher transmembrane pressures, gel layers (represented by limiting fluxes) were not encountered (Mameri et al., 1996; Belhocine et al., 1998; Belhocine et al., 2000). These results indicate that the raw water contained low concentrations of suspended solids and organic matter. For the treatment of the raw water, a tangential flow rate $\mathrm{U}=0.6 \mathrm{~m} / \mathrm{s}$ was utilised to reduce the negative impact of the polarisation layer during the production of drinking water with the ultrafiltration process operating without permeate recycling.

The distilled water permeability, representing the characteristic parameter of the ultrafiltration membrane, was determined for both new membranes and for membranes which previously had been subjected to raw water ultrafiltration. The results, presented in Fig. 3, show a linear increase in permeate flux with transmembrane pressure increase, which is in agreement with the Poiseuille law. It appears that the pure water permeabilities are of the same order with a permeability decrease of only about $5 \%$ after raw water ultrafiltration. The initial membrane permeability was always 


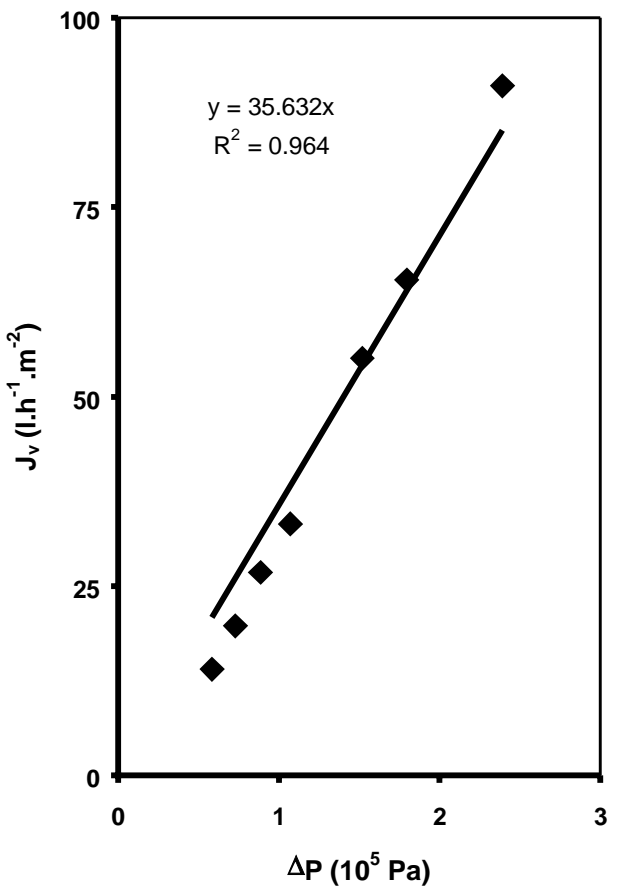

Figure 3

Hydraulic membrane permeability with (•) virgin membrane and (-) after raw water ultrafiltration

restored after a cleaning operation. Cleaning of the PCI membrane was carried out using dilute sulphuric acid $(\mathrm{pH} 4)$ at $30^{\circ} \mathrm{C}$ for 15 min.

\section{Variation of the water quality parameters}

Conductivity and $\mathrm{pH}$ of the concentrate and permeate were also monitored during raw water ultrafiltration at $U=0.6 \mathrm{~m} / \mathrm{s}$. It was found that the conductivity and $\mathrm{pH}$ of the two streams remained of the same order. This result may be explained by the fact that the ultrafiltration membrane was not able to modify the ionic strength of the raw water, particularly the $\mathrm{H}_{3} \mathrm{O}^{+}$ions and salt concentration. A considerable difference in turbidity was observed between the permeate and the concentrate solutions. Indeed, the turbidity of the permeate and concentrate solutions reached limiting values of 0.6 NTU and 2.5 NTU, respectively. These results indicate the ability of the ultrafiltration membrane to retain the suspended matter (Fig. 4).

It also showed that NOM is retained by the membrane yielding a permeate solution less charged in organic matter (Fig. 5).

To measure the efficiency of UF for treating raw water, apparent retention coefficients for turbidity $\left(\mathrm{R}_{\mathrm{Tur}}\right)$ and optic density $\left(\mathrm{R}_{\mathrm{OD}}\right)$ were determined. The apparent retention coefficients were calculated by the following equations:

$$
\begin{aligned}
& R_{T u r}(\%)=\left(1-\frac{T u r_{p}}{T u r_{c}}\right) X 100 \\
& R_{O D}(\%)=\left(1-\frac{O D_{p}}{O D_{c}}\right) X 100
\end{aligned}
$$

The values of $R_{O D}$ and $\mathrm{R}_{\text {Tur }}$ calculated for the various tangential flow rates $(U)$ and average transmembrane pressures (DP) showed that they were practically independent of the average transmembrane pressure and the tangential flow rate for the PCI membrane. They ranged from 20 to $30 \%$ for $R_{O D}$, and around $70 \%$ for $\mathrm{R}_{\text {Tur }}$. These

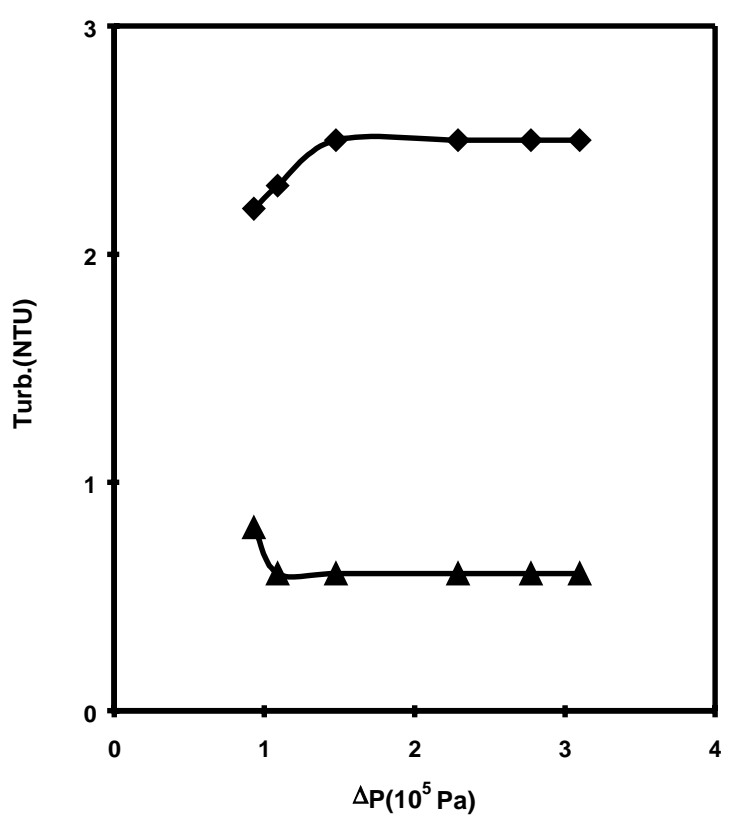

Figure 4

Changes of the turbidity for the raw water ultrafiltration with permeate recycling at various transmembrane pressures at $U=0.6 \mathrm{~m} / \mathrm{s}$

$(\bullet)$ concentrate and $(\mathbf{\Lambda})$ permeate

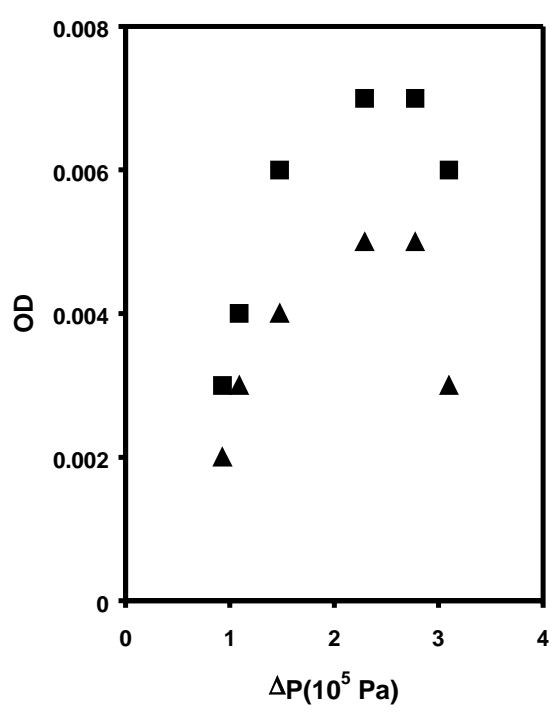

Figure 5

Changes in the optical density $(254 \mathrm{~nm})$ for raw water ultrafiltration with permeate recycling at various transmembrane pressures at $U=0.6 \mathrm{~m} / \mathrm{s}$

$(-)$ concentrate and $(\mathbf{\Lambda})$ permeate

results are in agreement with those obtained by others (Brahiti et al., 1994; Jolis et al., 1999; Van Hoof, 2000), indicating that ultrafiltration considerably reduces suspended solids and organic matter.

\section{Treatment of raw water without recycling permeate}

Treatment of the raw water was conducted under the optimum conditions determined during the previous recycle experiment. The tangential flow rate $U=0.6 \mathrm{~m} / \mathrm{s}$ was chosen as an optimum value to reduce the negative impact of the polarisation layer during 


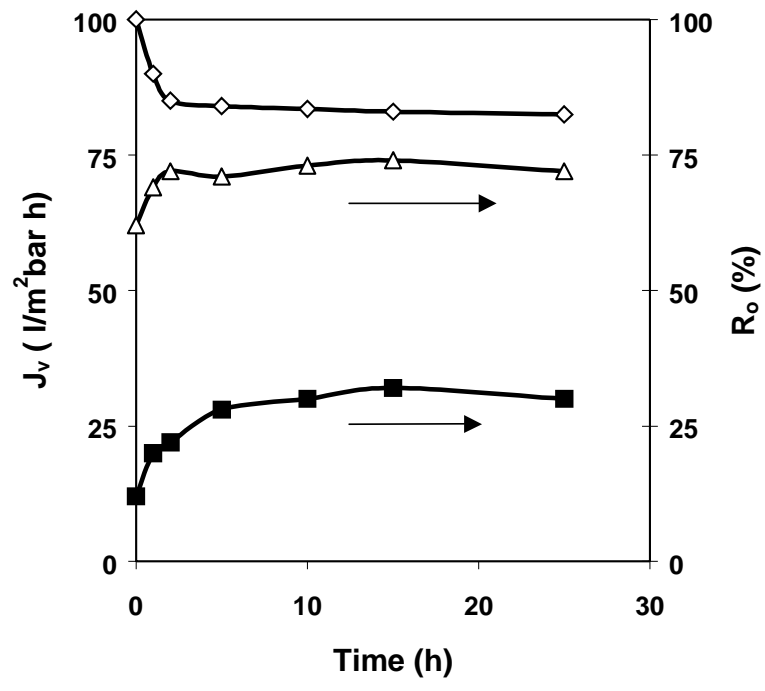

Figure 6

Changes in the permeate flux $(\diamond), R_{O D}(\cdot)$ and $R_{T u r}(\mathrm{D})$ during the treatment of the raw water without recycling permeate at $U=0.6 \mathrm{~m} / \mathrm{s}, T=20^{\circ} \mathrm{C}$ and $D P=2.5$ bars

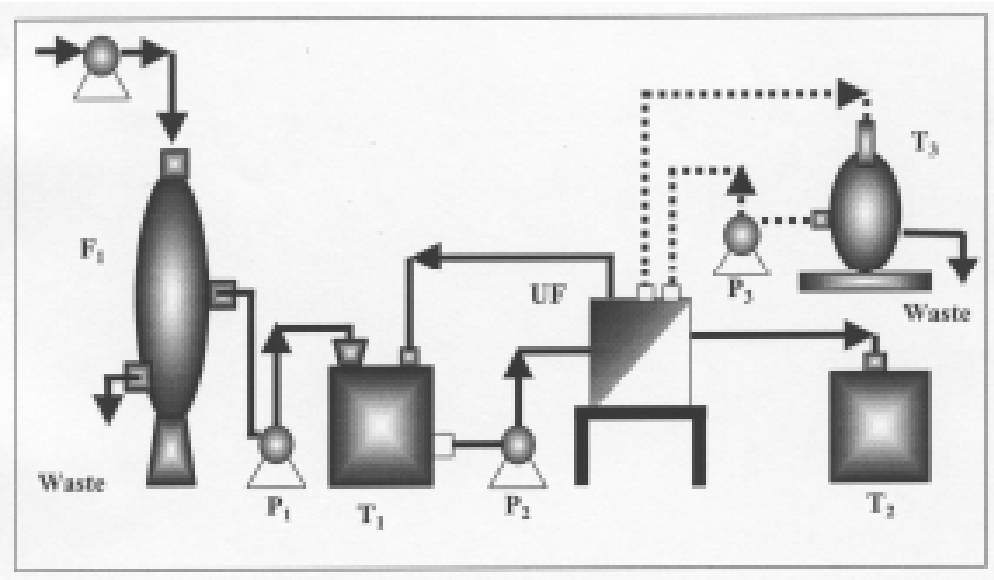

Figure 7

Schematic representation of the complete ultrafiltration unit

\begin{tabular}{|l|c|c|}
\hline \multicolumn{3}{|c|}{$\begin{array}{c}\text { TABLE } 2 \\
\text { Bacteriological quality of the raw water before and after } \\
\text { treatment }\end{array}$} \\
\hline Parameter & $\begin{array}{c}\text { Before treatment } \\
\text { Monthly average } \\
\text { range }\end{array}$ & $\begin{array}{c}\text { After ultrafiltration } \\
\text { Monthly average } \\
\text { range }\end{array}$ \\
\hline Total coliform & $\begin{array}{c}0.35-0.77 \\
\left(10^{6} \mathrm{cfu} / 100 \mathrm{~m} \ell\right)\end{array}$ & $\begin{array}{c}\text { Undetectable }- \\
1(\mathrm{cfu} / 100 \mathrm{~m} \ell)\end{array}$ \\
\hline Streptococcus group & $\begin{array}{c}0.3-0.5 \\
\left(10^{5} \mathrm{cfu} / 100 \mathrm{~m} \ell\right)\end{array}$ & $\begin{array}{c}\text { Undetectable } \\
(\mathrm{cfu} / 100 \mathrm{~m} \ell)\end{array}$ \\
\hline Enteric viruses & $\begin{array}{c}3-8 \\
\left(10^{5} \mathrm{u} / 100 \mathrm{~m} \ell\right)\end{array}$ & $\begin{array}{c}20-50 \\
(\mathrm{u} / 100 \mathrm{~m} \ell)\end{array}$ \\
\hline
\end{tabular}

the production of drinking water. The optimum transmembrane pressure (DP) retained was about $2.5 \times 10^{5} \mathrm{~Pa}$ giving a high permeate flux without changing the membrane porosity which may be damaged at higher DP. Permeate flux (Fig. 6) shows an initial flux which declines and rapidly reaches a steady-state value after an equilibrium period of $0.5 \mathrm{~h}$. The permeate flux reduction after equilibrium time was about $10 \%$ for the PCI membrane.

It was also observed that the $\mathrm{R}_{\mathrm{Tur}}$ and $R_{O D}$ reached steady-state values after equilibrium periods similar to that of permeate flux. These results indicate that it may be possible to obtain yields in the range of 95 to $98 \%$ as well as a long operation time before the membranes need chemical cleaning. The bacteriological quality of the water is considerably improved. Indeed, reduction factors of between $6 \log$ and $4 \log$ were obtained for bacteria and viruses, respectively (Table 2 ). These results on water quality are reassuring both for the population and the water companies.

\section{Economic evaluation of the UF process}

The membrane technique makes it possible to improve water quality, but the ultrafiltration process does not require softening pretreatments depending on the membrane type and the mineralisation of the treated water. The complete UF unit is presented in Fig. 7. The natural surface water was, first, passed through the cartridge filter $F_{1}$ $(100 \mathrm{~mm})$ as a prefiltration step, before transfer to the feed tank $T_{1}$ of the UF unit. This first step requires utilisation of the pump $P_{1}$.

The water stored in the feed tank $T_{1}$ is pumped under the required pressure to the UF unit by means of the pump $\mathrm{P}_{2}$. The water treated by the ultrafiltration unit is stored in tank $T_{2}$ which serves the urban water network. The concentrate solution produced by the ultrafiltration process is transferred temporarily to the $\operatorname{tank} \mathrm{T}_{3}$ and is pumped by $\mathrm{P}_{3}$ to the exposition area built for water elimination by natural evaporation.

\section{Dimensions and evaluation of the main equipment of the UF process}

The ultrafiltration process splits the feed water into two: the permeate product and the retentate concentrate streams. The quality of these solutions is linked to the water analysis, the transmembrane pressure, the yield and concentration in the retentate streams. The results previously presented made it possible to establish appropriate operating conditions for the ultrafiltration process, which are as follows:

- Transmembrane pressure: 250 - $300 \mathrm{kPa}$ that gives a high permeate pressure without altering the porosity of the membrane,

- Yield: 95 to $98 \%$ obtained as well as the long operation time before the membranes need chemical cleaning,

- Concentrate stream: maximum solubility of the dissolved matter.

These conditions were utilised to predict the dimensions and the design of a $20 \mathrm{~m}^{3} / \mathrm{h}$ ultrafiltration unit. The results obtained are reported in Table 3 . The cost of the ultrafiltration membranes and modules is about $\$ 61700$. It is important to add to this the cost of the 
membrane cleaning operation which requires a $3 \mathrm{~m}^{3}$ mixing vessel and a pump for the injection of the cleaner solution into the ultrafiltration unit and into all the pipes comprising the unit. The cost of the cleaning equipment is estimated at $\$ 6825$.

Estimation for all the equipment composing the ultrafiltration unit is presented in Table 4. The total cost is about $\$ 104250$. It is important to consider the cost induced by auxiliary equipment such as regulation apparatus, control and measuring apparatus, electric power installations and electric switchgear. Estimation of these items is expressed as a percentage of the cost of the main equipment (see Table 5). The civil infrastructure for the treatment of the concentrate solution consists in the realisation of a contrived area with a surface of $200 \mathrm{~m}^{2}$, calculated with evaporation capacity in the range of 8 to $10 \times 10^{-3} \mathrm{~m}^{3} / \mathrm{hm}^{2}$. The cost of the civil engineering works is valuated at $\$ 14000$.

The site, where the ultrafiltration unit and the control room etc. will be installed, has a surface area of about $400 \mathrm{~m}^{2}$ and their cost is estimated at $\$ 56000$. The total cost for civil engineering works and infrastructure is about $\$ 70000$.

The subtotal cost to realise the ultrafiltration unit for the treatment of the surface water from Keddara Dam, presented in Table 6, is obtained by addition of the cost of the main components previously presented, transport and installation costs of all the main equipment and their spare parts. Estimation of these is also expressed as a percentage of the cost of the main equipment.

The total cost is obtained by multiplying the subtotal previously obtained by 1.1 . The added $10 \%$ contingency represents engineering studies and all other costs that have not been considered. The total cost to realise the ultrafiltration treatment facility for the production of $20 \mathrm{~m}^{3} / \mathrm{h}$ is about $\$ 210000$.

\section{The economic performance of the processes}

The performance of the process is evaluated on the basis of $8000 \mathrm{~h} / \mathrm{yr}$ operating time. The cost price of the $/ \mathrm{m}^{3}$ of treated water is determined by taking into account the power costs, the membrane replacement cost, the consumables, the maintenance cost, the interest on the invested capital, and the amortised capital and labour costs.

Table 7 gives the cost of the ultrafiltration process. The consumable costs are estimated at $\$ 0.005 / \mathrm{m}^{3}$, whereas, maintenance costs and the interest on invested capital are fixed at 1.5 and $3 \%$ per year of the invested capital, respectively. Fifteen years amortised capital cost is considered for the process. The labour costs in North Africa may be considered to be negligible compared with the other cost items.

\section{Conclusion}

Ultrafiltration appears to be efficient for reducing the suspended matter and the natural organic matter present in raw water. The results obtained indicate that it may be possible to produce drinking water from surface water.

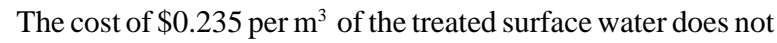
seem expensive, since the people in the region buy bottled drinking water at $\$ 0.2$ per litre. This solution could therefore be considered by the states of the North African region.
TABLE 3

Cost of the UF modules and membrane elements

\begin{tabular}{|l|c|c|c|}
\hline Item & Number & $\begin{array}{c}\text { Unit price } \\
(\mathbf{\$})\end{array}$ & Total \\
\hline $\begin{array}{l}\text { UF modules } \\
\text { Membranes elements } \\
(18 / \text { module })\end{array}$ & 40 & 1000 & 40000 \\
Diaphragms and parts & $/$ & 1700 & 20000 \\
& & 500 & 1700 \\
\hline \multicolumn{2}{|r|}{ Total: } & 61700 \\
\hline
\end{tabular}

TABLE 4

Estimation of the equipment composing the UF process

\begin{tabular}{|c|l|r|}
$\begin{array}{c}\text { Item } \\
\text { reference }\end{array}$ & Description & Cost (\$) \\
\hline F3 & Cartridge filter & 3000 \\
P1 & Pump for the transfer of pre-treated water & 5500 \\
P2 & Air compressor & 5875 \\
T1 & Tank of pretreated water & 4000 \\
UF & UF unit & 61700 \\
T2 & Tank for the storage of treated water & 6700 \\
T3 & Tank of the concentrate solution & 4000 \\
P4 & UF feed pump & 3000 \\
P5 & Pump for the transfer of concentrate solution & 3650 \\
- & Cleaning material & 6825 \\
\hline \multicolumn{2}{|c|}{ Total (\$) } & 104250 \\
\hline
\end{tabular}

TABLE 6

Total cost for the realisation of the UF process

\begin{tabular}{|l|r|}
\hline Item & Cost (\$) \\
\hline Main materials & 104250 \\
Installation of the equipment (10\%) & 10425 \\
Transport of the main materials (3\%) & 3130 \\
Auxiliary equipment & 66720 \\
Civil infrastructure and engineering & 70000 \\
Spare parts (5\%) & 5210 \\
Construction site insurance (1\%) & 1040 \\
Subtotal & 190775 \\
Engineering studies and all other costs (10\%) & 19100 \\
\hline
\end{tabular}




\begin{tabular}{|l|c|}
\hline \multicolumn{2}{|c|}{$\begin{array}{c}\text { TABLE 7 } \\
\text { Process performance }\end{array}$} \\
\hline Item & UF \\
& $\left(\$ / \mathbf{m}^{3}\right)$ \\
\hline Power costs $(0.05 \$ / \mathrm{kWh})$ & 0.010 \\
Membrane replacement (life-time 5 years) & 0.025 \\
Consumables (cleaning products, cartridge filtration) & 0.005 \\
Maintenance costs $(1.5 \%$ per year of the investment) & 0.026 \\
Interest on the invested capital (3\% per year of the investment) & 0.052 \\
Amortised capital cost (in 15 year period) & 0.117 \\
Labour costs (assumed to be negligible) & $/$ \\
\hline Total: $\left(\$ / \mathrm{m}^{3}\right)$ & 0.235 \\
\hline
\end{tabular}

\section{References}

ANSELME C , CHEVALIER MR, MAZOUNIE P and MALLEVIALLE J (1992) Applications industrielles de l'ultrafiltration pour la production d'eau potable. Bilan de fonctionnement des installations. Perspectives d'évolution, Tech. Sci. Munic. 9 403-408.

ASM (1987) Manual of Methods for General Bacteriology. Am. Soc. for Microbiol., Washington, DC.

BELHOCINE D, MOKRANE H, GRIB H, PAUSS A and MAMERI N (2000) Membrane fouling during recovery of papain enzyme. Chem. Eng. J. 76 (3) 189-196.

BELHOCINE D, GRIB H, ABDESMED D, COMEAU Y and MAMERI N (1998) Optimization of plasma protein concentration by ultrafiltration. J. Membr. Sci. 142 159-171.

BERSILLON JL, ANSELME C, MALLEVIALLE J, APTEL P and FIESSINGER F (1989) L'ultrafiltration appliquée au traitement de l'eau potable: Le cas d'un petit système. Eau Ind. Nuisances 1 61-64.

BRAHITI SE, DAKHI S, ABDESSMED D, GAID A and MAMERI N (1994) Traitement tertiaire des eaux usées par ultrafiltration. Trib. CEBEDEAU 571 (5) 39-43.

BRUGGER A (2000) Reuse of filter backwash water using ultrafiltration technology. Filtr. Sep. 37 (1) 22-26.
JOLIS D, HIRANO R and PITT P (1999) Tertiary treatment using microfiltration and UV disinfection for water reclamation. Water Environ. Res. 71 (2) 224-231.

LIN CF, LIN T-Y and HAO OJ (2000) Effects of humic substance characteristics on UF performance. Water Res. 34 (4) 1097-1106.

LEFEBVRE E (1995) Etude par des paramètres globaux de la matière organique d'eaux brutes et clarifiées. Rev. Sci. Eau 8 (2) 125-150.

MAGARA Y, KUNICANE S and ITOH M (1998) Advanced membrane technology for application to water treatment. Water Sci. \& Technol. 37 (10) 91-99.

MAMERI N, ABDESMED D, BELHOCINE D, LOUNICI H, GAVACH C, SANDEAUX J and SANDEAUX R (1996) Treatment of fishery washing waters by ultrafiltration. J. Chem. Biotechnol. 67 169-175.

TAZI-PAIN A, FAIVE M and BOURBIOT M (1992) Comparaison des techniques membranaires pour le traitement des eaux de surface chargées en matières organiques: perspectives d'évolution. Tech. Sci. Munic. 9 411-415.

YUASA A (1998) Drinking water production by coagulation-microfiltration and adsorption-ultrafiltration. Water Sci. \& Technol. 37 (10) 135-146.

VAN HOOF S (2000) Semi dead-end ultrafiltration in potable water production. Filtr. Sep. 37 (1) 28-30. 